\title{
Removal of Zn(II) from electroplating effluent using yeast biofilm formed on gravels: batch and column studies
}

\author{
Geetanjali Basak ${ }^{1 \dagger},{\text { Lakshmi } V^{1 \dagger} \text {, Preethy Chandran }}^{2 \dagger}$ and Nilanjana Das ${ }^{1 *}$
}

\begin{abstract}
Background: Present study deals with the removal of $\mathrm{Zn}(\mathrm{II})$ ions from effluent using yeast biofilm formed on gravels.

Methods: The biofilm forming ability of Candida rugosa and Cryptococcus laurentii was evaluated using XTT (2,3-bis [2-methoxy-4-nitro-5-sulfophenyl]-2H-tetrazolium-5-carboxanilide) reduction assay and monitored by scanning electron microscopy (SEM), and Confocal laser scanning microscopy (CLSM). Copious amount of extracellular polymeric substances (EPS) produced by yeast species was quantified and characterized by Fourier transform infrared spectroscopy (FT-IR).

Results: Yeast biofilm formed on gravels by C. rugosa and C. laurentii showed $88 \%$ and $74.2 \%$ removal of Zn(II) ions respectively in batch mode. In column mode, removal of Zn(II) ions from real effluent was found to be $95.29 \%$ by $C$. rugosa biofilm formed on gravels.

Conclusion: The results of the present study showed that there is a scope to develop a cost effective method for the efficient removal of Zn(II) from effluent using gravels coated with yeast biofilm.
\end{abstract}

Keywords: Biofilm on gravels, CLSM, Electroplating effluent, Packed bed column, Yeast, Zn(II) removal

\section{Introduction}

$\mathrm{Zn}$ (II) is a metal ion which is released into the environment through industrial activities at concentration of physiological and ecological concern. In the Dangerous substances Directive (76/464/EEC) of the European Union, zinc has been registered as List 2 dangerous substance [1]. It is one of the 13 metals found in the contamination list proposed by the United States Environmental Protection Agency (USEPA) [2]. The World Health Organisation (WHO) recommends a $5.0 \mathrm{mg} / \mathrm{L}$ maximum acceptable concentration of zinc in drinking water [3]. Zinc is phytotoxic, and the recommended level of zinc for disposal on agricultural land is $2.5 \mathrm{mg} / \mathrm{g}$ of dried sludge solids. Effluents from the industries such as manufacture of alloys, sheet metal galvanization, TV picture tubes etc. contain high concentrations of zinc. Discharging these effluents

\footnotetext{
* Correspondence: nilanjana00@lycos.com

${ }^{\dagger}$ Equal contributors

'Environmental Biotechnology Division, School of Bio- Sciences and

Technology, VIT University, Vellore, Tamil Nadu, India

Full list of author information is available at the end of the article
}

into natural systems adjoining landmasses and sewer systems is a normal practice in small and medium scale industries which poses serious problems to the environment and ecosystems. Therefore, there is a significant need regarding the removal of zinc from effluent [4].

Conventional methods for metal removal include precipitation, filtration, coagulation, evaporation, ion exchange, membrane separation and solvent extraction. However, application of such processes is always expensive and ineffective in terms of energy and chemical products consumption, especially at low concentrations of $1-100 \mathrm{mg} / \mathrm{L}$. Therefore, an alternate cost effective treatment strategy is required which will be eco- friendly. Though biosorption has been regarded as a cost effective technique for removal of $\mathrm{Zn}(\mathrm{II})$ ion using microorganisms such as bacteria [5-7], fungi [8,9] and yeast [10-12], application of biofilm may be a better choice for $\mathrm{Zn}(\mathrm{II})$ removal from effluent.

Biofilm is a kind of immobilization of microorganisms in a solid matrix and can be applied for bioremediation of effluents. During the last few decades, biofilm reactors

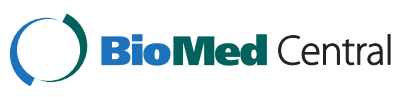


have become a focus of interests for the researchers in the field of bioremediation of pollutants. There are reports on the application of bacterial biofilm for zinc removal using granular activated carbon [13,14], moving bed sand filter [15] and combined AS- biofilm process [16]. Reports are scanty regarding the use of yeast biofilm for $\mathrm{Zn}$ (II) removal.

Biofilm formation in microorganisms is closely linked with production of extracellular polymeric substance (EPS) which acts as a glue, helping the attachment of cell surface to the submerged structures [17]. Extracellular polymeric substance are mainly composed of polysaccharides, proteins, humic substances and uronic acid [18] which contains several functional groups like carboxyl, phosphoric, amine and hydroxyl groups. EPS has various functions viz. induction of cell aggregation [19], producing a protective barrier for cell against harmful products and allowing sorption of inorganic ions from the environment [20]. There is report on the production of a water soluble $300 \mathrm{kDa}$ extracellular polymeric substance produced by yeast Candida albicans made up of glucose, mannose, ramnose and $\mathrm{N}$-acetyl glucosamine using gas chromatography, gel permeation chromatography, FTIR spectrophotometer, ${ }^{1} \mathrm{H}$ and ${ }^{13} \mathrm{C}$ NMR spectrophotometer [21].

For large scale effluent treatment, continuous flow operations in column mode are more useful than batch mode. However, little effort has been focused on column study using yeast biofilm for removal of $\mathrm{Zn}$ (II) ion from synthetic solutions.

The aim of the present study was (i) to study the biofilm forming ability of yeast isolates and monitoring of biofilm formation through microscopic analysis viz. SEM and CLSM (ii) to quantify the amount of extracellular polymeric substances (EPS) produced by yeast during biofilm formation and characterization of EPS through FT-IR analysis and (iii) to evaluate the process of $\mathrm{Zn}$ (II) removal by yeast biofilm in batch mode and to study the removal of $\mathrm{Zn}$ (II) ion from real effluent in continuous flow column reactor packed with, gravels coated with yeast biofilm.

\section{Materials and methods}

\section{Preparation of $\mathrm{Zn}$ (II) solution}

$\mathrm{Zn}$ (II) stock solution (1000 $\mathrm{mg} / \mathrm{L}$ ) was prepared by dissolving $4.55 \mathrm{~g}$ of powdered $\mathrm{Zn}\left(\mathrm{NO}_{3}\right)_{2} \cdot 6 \mathrm{H}_{2} \mathrm{O}$ (Hi Media, Mumbai, India) in $1000 \mathrm{ml}$ of deionised water. The working solutions of metal were prepared by diluting the stock solution to desired concentrations.

\section{Yeast and growth condition}

Two yeast species were isolated from Common Effluent Treatment Plant (CETP), Ranipet, Vellore, Tamilnadu, India. The yeasts were phenotypically characterized and identified to species levels as C. rugosa and C. laurentii by Vitek 2 Compact Yeast card reader with software version V2C 03.01 from Council for Food Research and Development (CFRD), Kerela, India. The isolates were subcultured in YEPD (yeast extract: $10 \mathrm{~g} / \mathrm{L}$; peptone: 20 $\mathrm{g} / \mathrm{L}$; dextrose: $20 \mathrm{~g} / \mathrm{L}$ ) agar slant and maintained at $4^{\circ} \mathrm{C}$. Sugarcane bagasse extract having $24 \mathrm{~g} / \mathrm{L}$ total sugar $(\mathrm{pH}$ 5.0) was used as media for the biofilm formation and $\mathrm{Zn}$ (II) removal studies.

\section{Analysis of effluent}

Effluent was collected from Krishna electroplating works, located at Kolkata, West Bengal, India. The physicochemical characteristics of effluent were analyzed promptly after collection using standard analytical methods [22]. The concentration of zinc, copper, nickel and cadmium present in effluent was analyzed using Atomic Absorption Spectrophotometer (Varian AA-240, Australia).

\section{Biofilm formation}

The gravels were collected from a local nursery at VIT University. The size of the gravels was made uniform at a size of $7.5 \mathrm{~mm}$ by passing through the mesh. They were dipped in $1 \mathrm{ml}$ culture with $5 \times 10^{8} \mathrm{CFU} / \mathrm{ml}$ of $48 \mathrm{~h}$ grown yeast species, placed for $90 \mathrm{~min}$ of adhesion phase at $28^{\circ} \mathrm{C}$ and were then washed with sterilized phosphate buffered saline to remove loosely adherent cells. One millilitre of sterilized sugarcane bagasse medium was added to the washed pieces and incubated at $28^{\circ} \mathrm{C}$ for $48 \mathrm{~h}$. The biofilm thus formed was then quantified using XTT reduction assay.

\section{XTT reduction assay}

XTT (sigma, St Louis, MO, USA) solution $(1 \mathrm{mg} / \mathrm{ml}$ in PBS) was prepared, filters sterilized through a $0.22 \mu \mathrm{m}$ pore size filter and stored at $-70^{\circ} \mathrm{C}$. Menadione (sigma) solution $(0.4 \mathrm{mM})$ was prepared and filter sterilized immediately before each assay. Prior to each assay, XTT solution was thawed and mixed with the menadione solution at a ratio of 5 to 1 by volume. The biofilms formed on gravels were first washed five times using $1 \mathrm{ml}$ of PBS, and then $1 \mathrm{ml}$ of PBS and $60 \mu \mathrm{l}$ of XTTmenadione solution were added to each of the prewashed and control tubes. The tubes were then incubated in the dark for $2 \mathrm{~h}$ at $28^{\circ} \mathrm{C}$. Following incubation, the colour change in the solution was measured spectrophotometrically at $492 \mathrm{~nm}$ (Hitachi U-2800) [21].

\section{Morphological characterization of yeast biofilm}

Yeast biofilm formed on gravels were morphologically characterized using Scanning electron microscopy (Stereo Scan LEO, Model -400) following the method of Hawser and Doughlas [23] and Confocal laser scanning microscopy 
(Olympus FV 1000, America) following the method of Sundar et al. [24].

\section{Recovery and characterization of Extracellular polymeric substance}

Extracellular polymeric substance (EPS) was isolated from culture supernatants of yeast species using acetone precipitation technique [25]. The carbohydrate composition of EPS was also determined using HPLC (chromatograph Waters, Milford, MA, USA) following the method of Simova et al. [26]. The dialysed EPS was characterized through infrared analysis using FT-IR spectrophotometer (Perkin Elmer Spectrum 1).

\section{Batch studies on $\mathrm{Zn}$ (II) removal using yeast biofilm formed on gravels}

Yeast biofilm formed on gravels were washed with phosphate buffer to remove the loosely attached cells. The washed gravels were then used for batch studies. In order to study the effect of growth supportive media on $\mathrm{Zn}$ (II) removal by yeast biofilm, the batch experiments were conducted by immersing the washed gravels in $\mathrm{Zn}$ (II) solution with and without sterilized sugarcane bagasse extract at $\mathrm{pH}$ 5.0. The temperature was maintained at $28^{\circ} \mathrm{C}$. To study the effects of $\mathrm{pH}$, temperature and initial $\mathrm{Zn}$ (II) concentration on $\mathrm{Zn}$ (II) removal, experiments were conducted at different $\mathrm{pH}$ ranging from 2-8, temperature ranging from $20-40^{\circ} \mathrm{C}$ and initial $\mathrm{Zn}$ (II) concentration ranging from $10-100 \mathrm{mg} / \mathrm{L}$. The dry weight of the biofilm biomass (including yeast cells and EPS) was measured at regular intervals of time. The preweighed gravels with attached biofilm were removed from experimental flasks, carefully blotted to remove excess medium without disrupting the biofilm, dried and weighed. Liquid samples were withdrawn at regular intervals and centrifuged at 10,000 rpm for $5 \mathrm{~min}$. Supernatants were subjected to AAS analysis for residual $\mathrm{Zn}$ (II) concentration. All experiments were performed in triplicates and the data presented are mean of triplicates. The $\mathrm{Zn}$ (II) removal percentage using yeast biofilm was calculated from the following equation:

$$
\frac{C_{i}-C_{f}}{C_{i}} \times 100
$$

Where $\mathrm{C}_{i}$ is the initial concentration of $\mathrm{Zn}$ (II) ion $(\mathrm{mg} / \mathrm{L}) . \mathrm{C}_{f}$ is the final concentration of $\mathrm{Zn}(\mathrm{II})$ ion $(\mathrm{mg} / \mathrm{L})$.

Removal of Zn(II) from electroplating effluent in column mode using yeast biofilm

A glass column with an internal diameter of $3 \mathrm{~cm}$ and height $15 \mathrm{~cm}$ was employed in the column experiments. The column was packed with gravels coated with yeast biofilm. Effluent collected from electroplating industry containing $85 \mathrm{mg} / \mathrm{L} \mathrm{Zn}$ (II) ions was used in this experiment. Before passing through the column, effluent was mixed with sugarcane bagasse extract, $\mathrm{pH}$ was adjusted to 6.0 and fed through the column at a desired flow rate using a peristaltic pump. To study the effect of bed height on $\mathrm{Zn}$ (II) removal in column mode, experiments were conducted at three different bed heights viz. 4, 8 and $12 \mathrm{~cm}$. The effect of flow rate on $\mathrm{Zn}$ (II) ion removal was studied at three different flow rates viz. 1,3 and $5 \mathrm{ml} / \mathrm{min}$. Samples collected from the exit of the column at different time intervals were analyzed by AAS. Effluent was passed through the column till the values reached the US EPA standard (5.0 mg/L).

\section{Results and discussion}

Yeast biofilm formation

The adherence and subsequent biofilm formation by the yeast species viz. C. rugosa and C. laurentii on gravels over $72 \mathrm{~h}$ were studied using XTT reduction assay. The production of the soluble coloured formazan salt from biofilm forming cells on gravels was a direct reflection of cellular metabolic activity which increased with time (Figure 1). It was evident that the yeast species were capable of biofilm formation.

\section{Morphological characterization}

Surface morphology of the biofilms was studied by SEM images. In the initial adherence phase $(12 \mathrm{~h})$, the yeast species started colonization on gravels and as the biofilms matured, aggregation complexity increased with time (Figure 2A-C) and (Figure 3A-C).

Exopolysaccharide production by yeast species was also noted through SEM images. The physical appearance of a developing biofilm as a net like structure consisting of

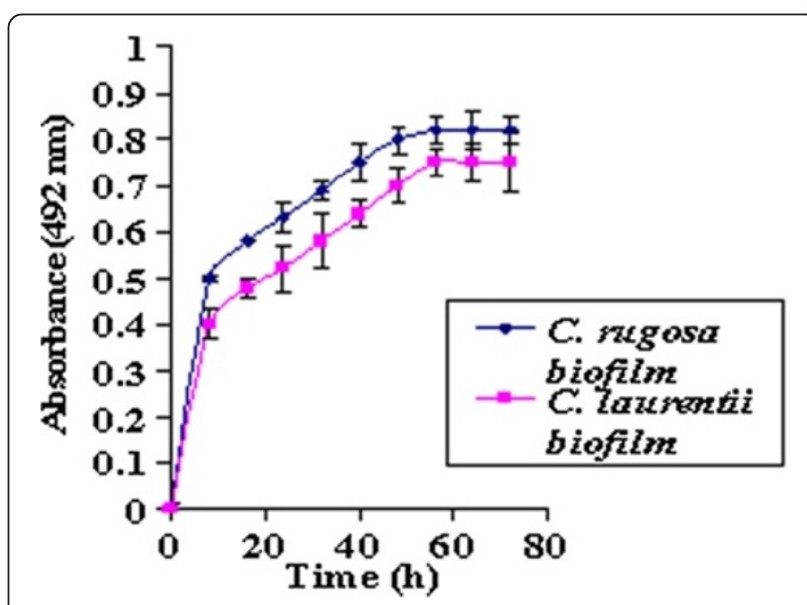

Figure 1 Yeast biofilm formation on gravels determined by XTT reduction assay. 

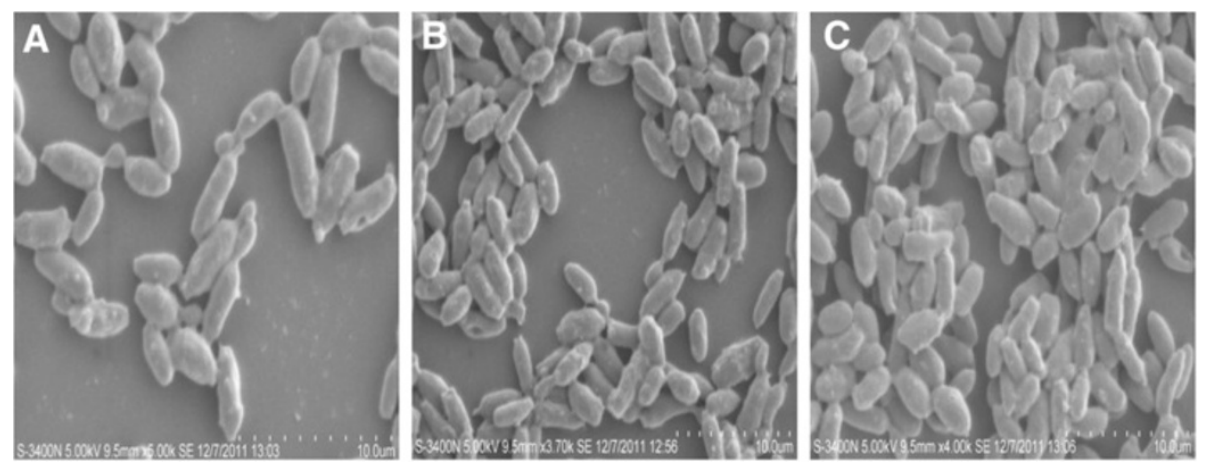

Figure 2 SEM images showing sequential biofilm formation by C. rugosa on PVC strips during: (A) $12 \mathrm{~h}$; (B) $24 \mathrm{~h}$ and (C) $48 \mathrm{~h}$.

yeast strung together and bound by polysaccharide coating were observed in case of C. rugosa (Figure 4A) and C. laurentii (Figure 4B). This coating provided sites for the attraction of positively charged metal ions allowing it to act as an ion-exchange medium [13].

Formation of yeast biofilms were analysed by CLSM. The uninteracted biofilms on gravels showed more thickness of biomass than the thickness of $\mathrm{Zn}$ (II) interacted biofilms. Figure 5A(i) and Figure 6A(i) showed average projections of CLSM z-series images from uninteracted biofilms formed by C. rugosa and C. laurentii respectively. Figure $5 \mathrm{~A}$ (ii) and Figure $6 \mathrm{~A}$ (ii) showed the thickness of biofilm with z-stacks three-dimensional (3D) reconstruction respectively for C. rugosa and $C$. laurentii. Thickness of the uninteracted biofilms was calculated as $51.06 \pm 1.25 \mu \mathrm{m}$ for C. rugosa and $45.03 \pm$ $2.37 \mu \mathrm{m}$ for $C$. laurentii. The thickness of biofilm decreased to $37.60 \pm 2.89 \mu \mathrm{m}$ for $C$. rugosa (Figure $5 \mathrm{~B}(\mathrm{i}$ ) and Figure $5 \mathrm{~B}(\mathrm{ii}))$ whereas in case of $C$. laurentii the thickness of biofilm was reduced to $34.78 \pm 3.54 \mu \mathrm{m}$ (Figure $6 \mathrm{~B}(\mathrm{i}$ ) and Figure 6B(ii)) after $\mathrm{Zn}(\mathrm{II})$ interaction for $12 \mathrm{~h}$.

\section{Recovery of extracellular polymeric substance (EPS)}

EPS was recovered by acetone precipitation technique. Growth for 7 days in 1 litre medium, an EPS yield of
$28.2 \%$ by C. rugosa and $18.5 \%$ by C. laurentii was obtained by precipitation of culture supernatants with acetone. Figure 7 showed the percentage yield of EPS produced by the yeast species at different time intervals. EPS formation protects the yeast cells from environmental chemical toxicity [27].

\section{Characterization of EPS}

The sugar composition of EPS produced by C. rugosa and $C$. laurentii were analysed using HPLC (water 2487 model). The HPLC chromatogram (Figure 8A) showed the presence of three individual sugars viz., glucose (25.59\%), mannose (36.14\%) and glucuronic acid $(17.79 \%)$ at $1.541,1.785$ and 1.909 retention times, respectively for EPS produced by C. rugosa. Figure 8(B) showed the HPLC peaks which revealed the presence of glucose (18.5\%), mannose (33.35\%) and glucuronic acid (16.12\%) at 1.572, 1.793 and 1.943 retention times, respectively in case of C. laurentii. Therefore, the present results indicated that glucose, mannose and glucuronic acids were the most abundant sugars in EPS produced by C. rugosa and C. laurentii. Similar work was reported in case of yeasts belonging to Candida, Cryptococcus, Rhodotorula and Sporobolomyces genera which produced EPS
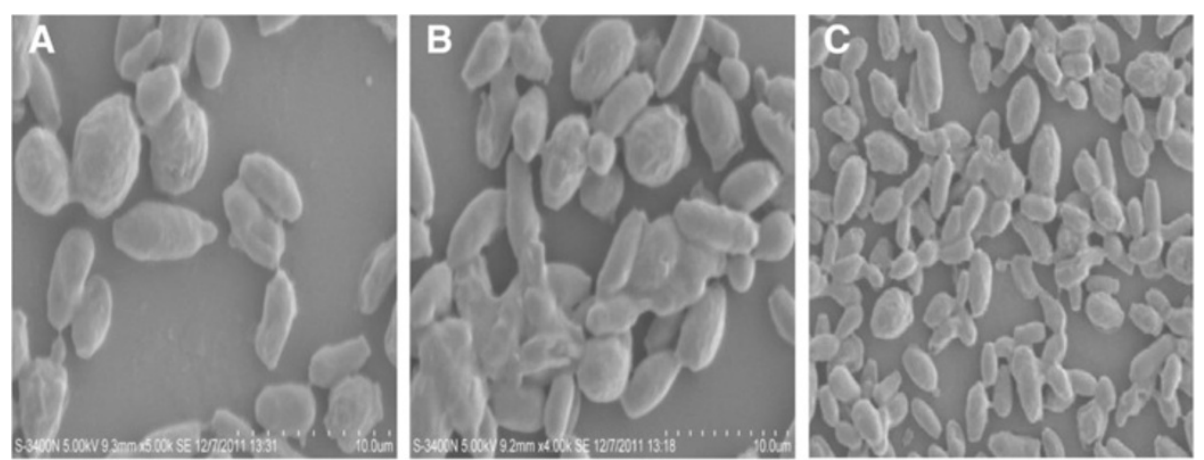

Figure 3 SEM images showing sequential biofilm formation by C. laurentii on PVC strips during: (A) 12 h (B) 24 h and (C) 48 h. 

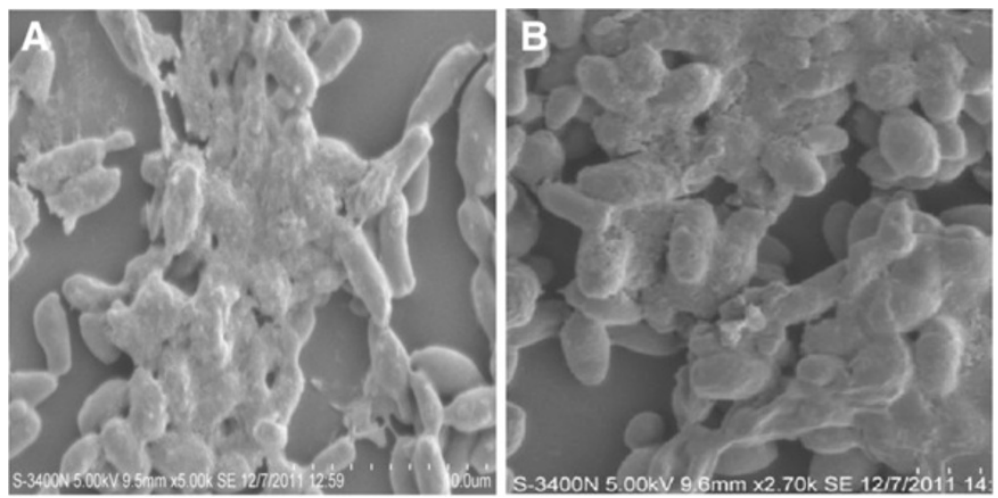

Figure 4 SEM images showing exopolysaccharide (EPS) production by biofilm forming: (A) C. rugosa and (B) C. laurentii.

such as mannan, glucomannan and glucan [26,28-30]. Since the EPS produced by yeast are more easily separated from the culture broth than those produced by bacteria; they are more attractive for a large scale production [31].

\section{FT-IR analysis of EPS}

FTIR spectroscopy opens up new possibilities for the fine structural analysis of polysaccharides and its derivatives. In order to investigate the functional groups of the purified EPS, the FT-IR spectra were measured in $\mathrm{KBr}$
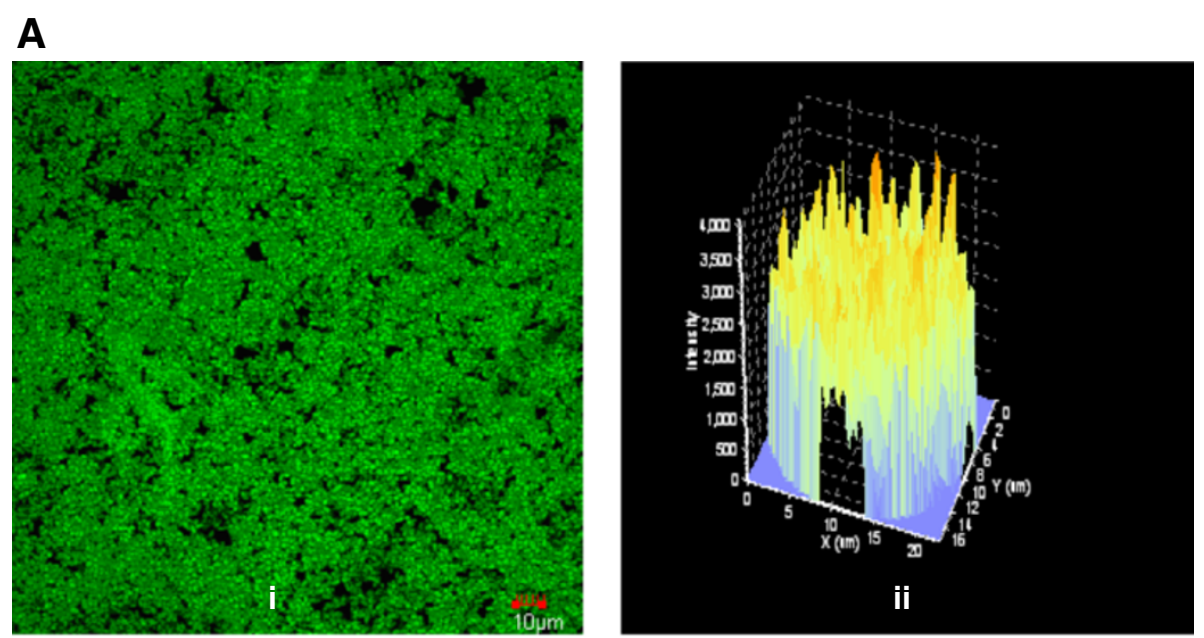

\section{B}
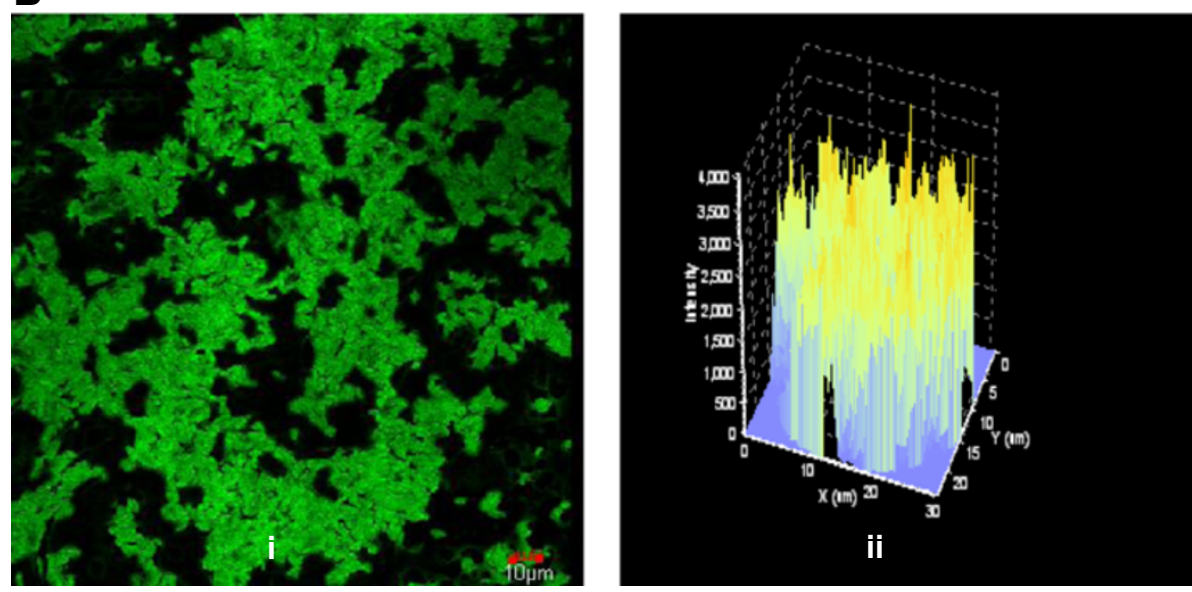

Figure 5 CLSM imaging of (A) uninteracted and Zn(II) (B) interacted C. rugosa biofilm after $72 \mathrm{~h}$ of growth. 

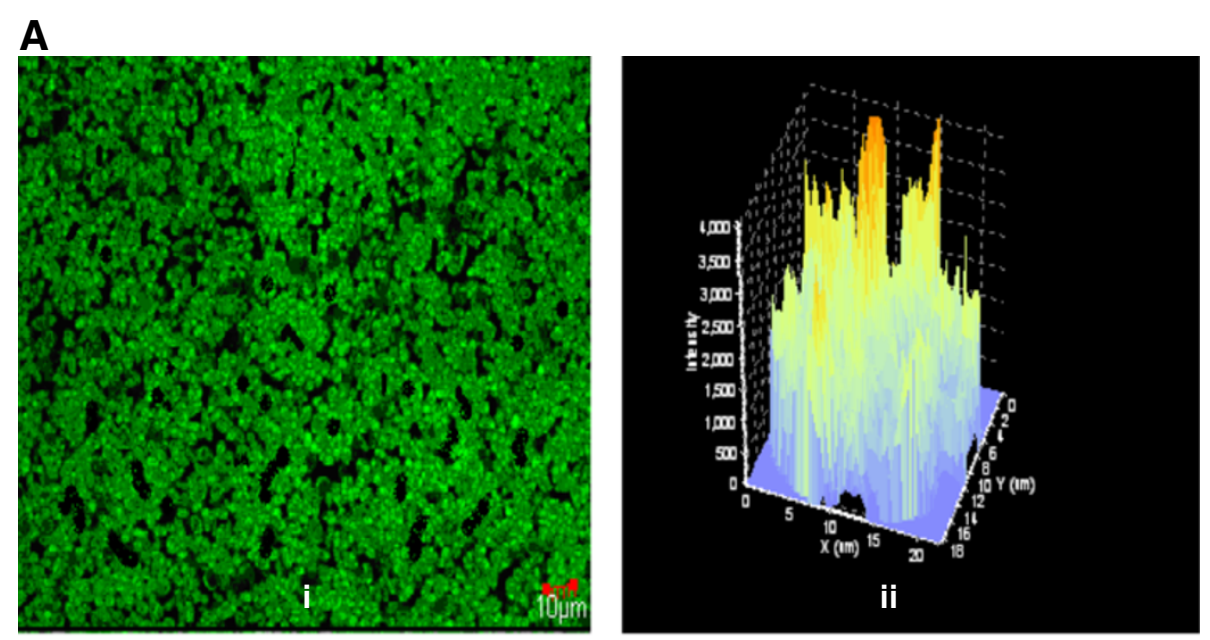

B
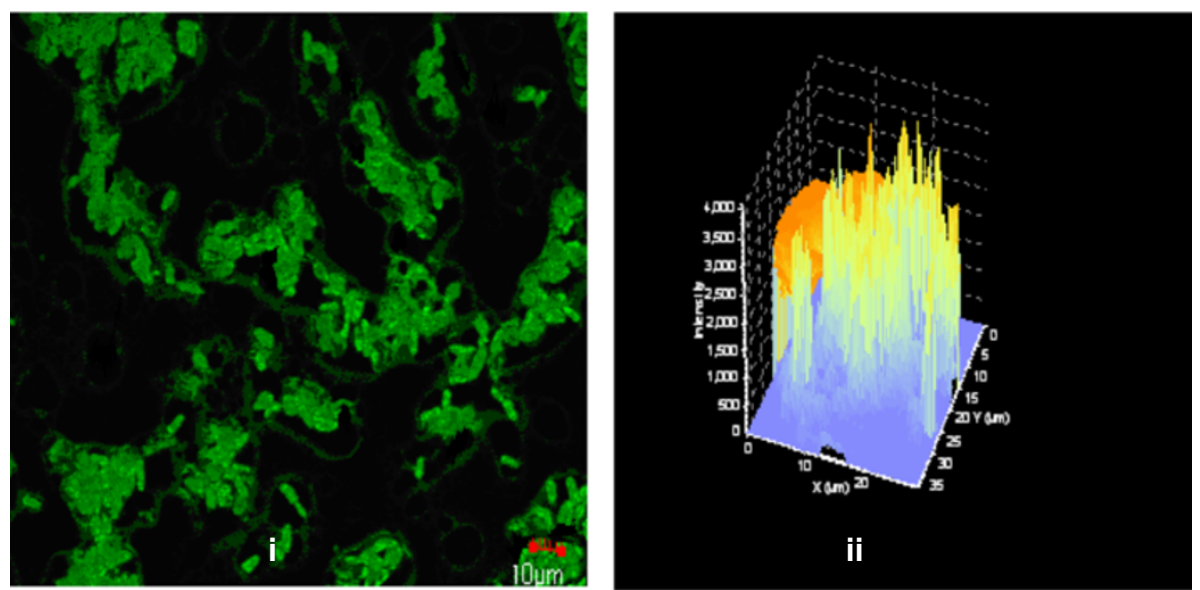

Figure 6 CLSM imaging of (A) uninteracted and Zn(II) (B) interacted C. laurentii biofilm after $72 \mathrm{~h}$ of growth.

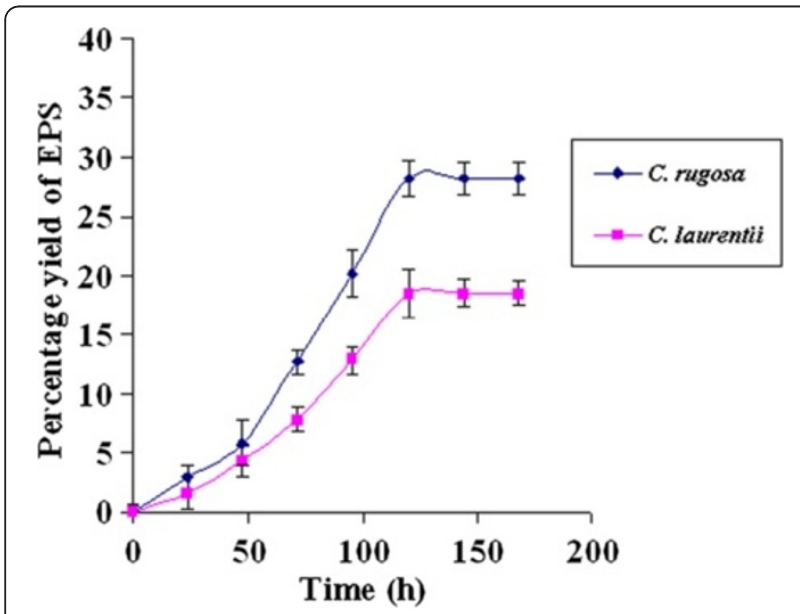

Figure 7 Time course of exopolysaccharide synthesis. (temperature: $28^{\circ} \mathrm{C}$; time: $168 \mathrm{~h}$ ). pellets. Typical IR spectra for the EPS produced by two yeast species C. rugosa and C. laurentii are presented in Figure 9(A) and Figure 9(B) respectively. The broad and the strong stretching bonds at $3339 \mathrm{~cm}^{-1}$ (C. rugosa) and $3401 \mathrm{~cm}^{-1}$ (C. laurentii) indicated bounded hydroxyl $(-\mathrm{OH})$ group.

The absorption bands at $2932 \mathrm{~cm}^{-1}$ (C. rugosa) and $2936 \mathrm{~cm}^{-1}$ (C. laurentii) were intensified and assigned to the stretching vibration of the methylene group $(\mathrm{C}-\mathrm{H})$. Furthermore, a continuous absorption beginning at approximately in the region of $3339 \mathrm{~cm}^{-1}$ for C. rugosa and $3401 \mathrm{~cm}^{-1}$ for $C$. laurentii are the characteristic of a carbohydrate ring. In comparison with the IR spectra of polysaccharides documented in literature, a characteristic absorption band appeared at $1652 \mathrm{~cm}^{-1}$ for the exopolysaccharide produced by both the yeast species. The absorption band at $1652 \mathrm{~cm}^{-1}$ were assigned to the stretching vibration of the carboxyl group $(C=O)$. The peaks observed at $1410 \mathrm{~cm}^{-1}$ and $1318 \mathrm{~cm}^{-1}$ for 


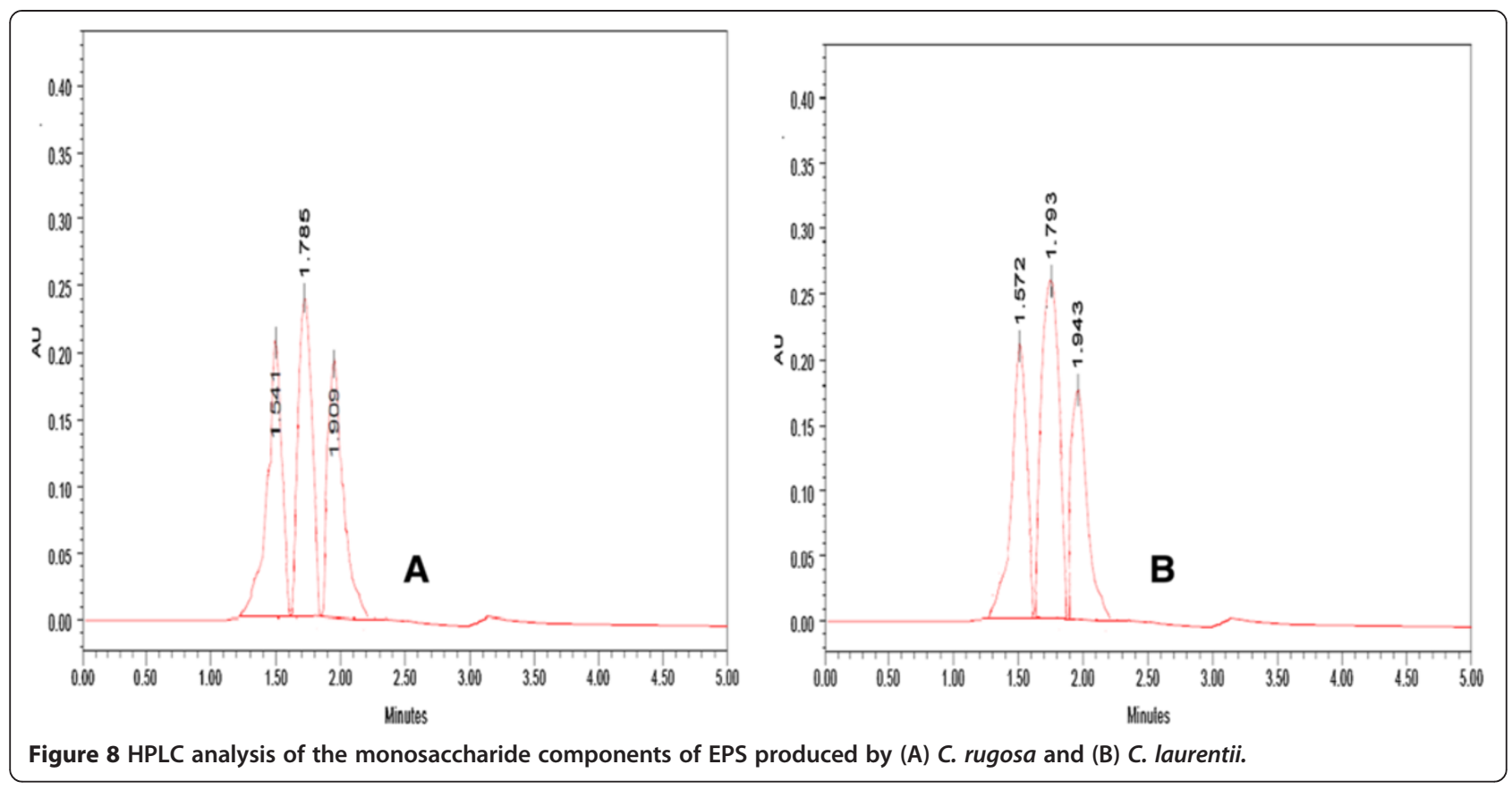

C. laurentii is the symmetric stretching vibrations of carboxylic group $\left(-\mathrm{COO}^{-}\right)$. A broad stretching of $\mathrm{C}-\mathrm{O}-\mathrm{C}$, $\mathrm{C}-\mathrm{O}$ at $1000-1200 \mathrm{~cm}^{-1}$ indicated the presence of carbohydrates [32]. Specifically, the absorption band appeared at $1088 \mathrm{~cm}^{-1}$ (C. rugosa) and $1079 \mathrm{~cm}^{-1}$ (C. laurentii) ascertains the presence of uronic acid, o-acetyl ester linkage bonds. The presence of acidic sugars in the EPS may be important, considering the heavy metal- binding properties of the polymers [33]. In addition, the absorption bands in the region $900-800 \mathrm{~cm}^{-1}$ were associated to the glycosidic linkage types in polysaccharides. The absorption peaks at $910 \mathrm{~cm}^{-1}$ and $861 \mathrm{~cm}^{-1}$ in the EPS produced by C. rugosa and absorption peaks at 912 $\mathrm{cm}^{-1}$ and $875 \mathrm{~cm}^{-1}$ in C. laurentii exopolysaccharide revealed the coexistence of $\alpha$ and $\beta$ glycosidic bonds [34]. Similar FT-IR results were reported by Ma et al. [35].
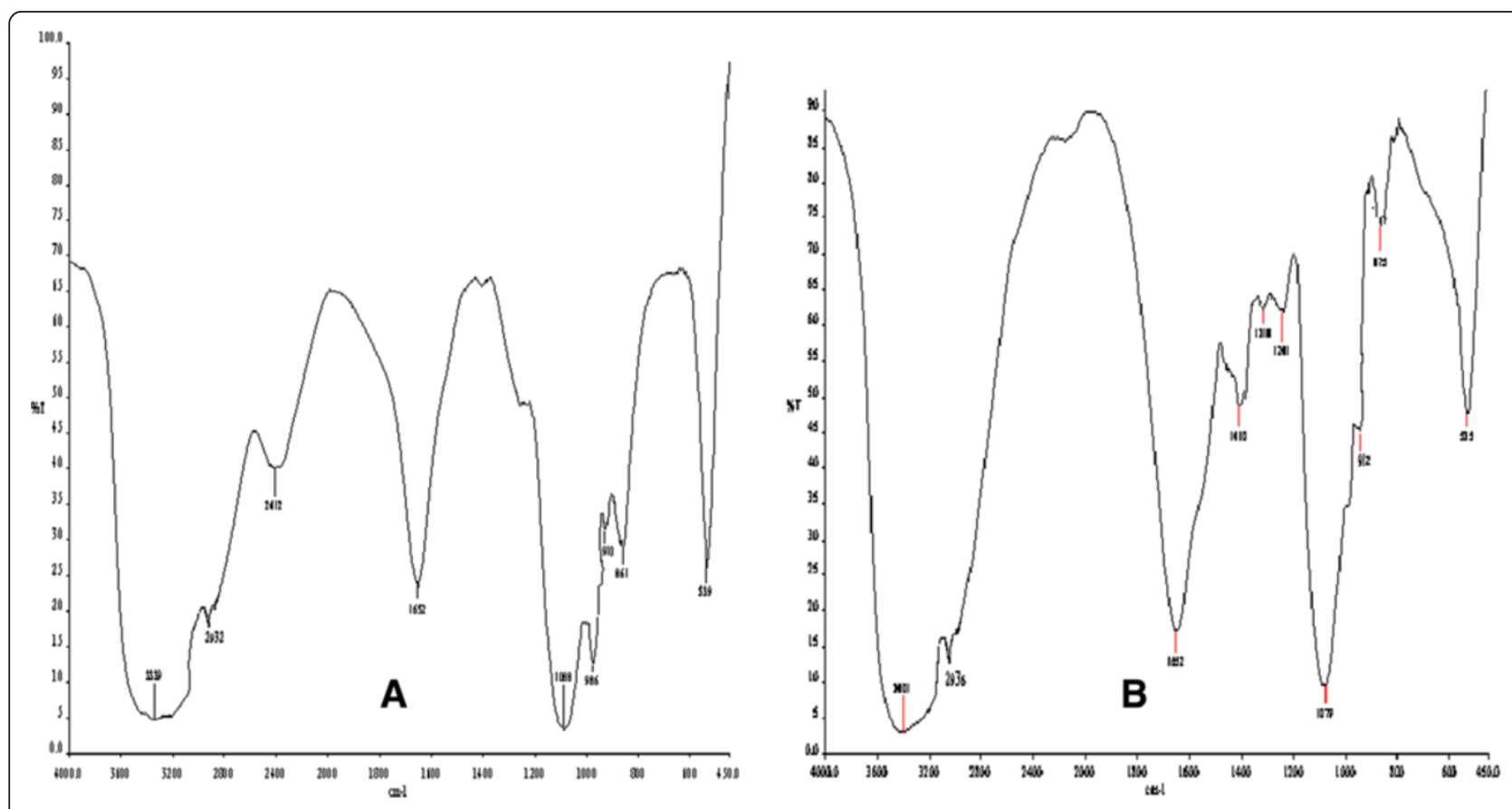

Figure 9 FT-IR spectra of the exopolysaccharides produced by yeast biofilm (A) C. rugosa and (B) C. laurentii. 

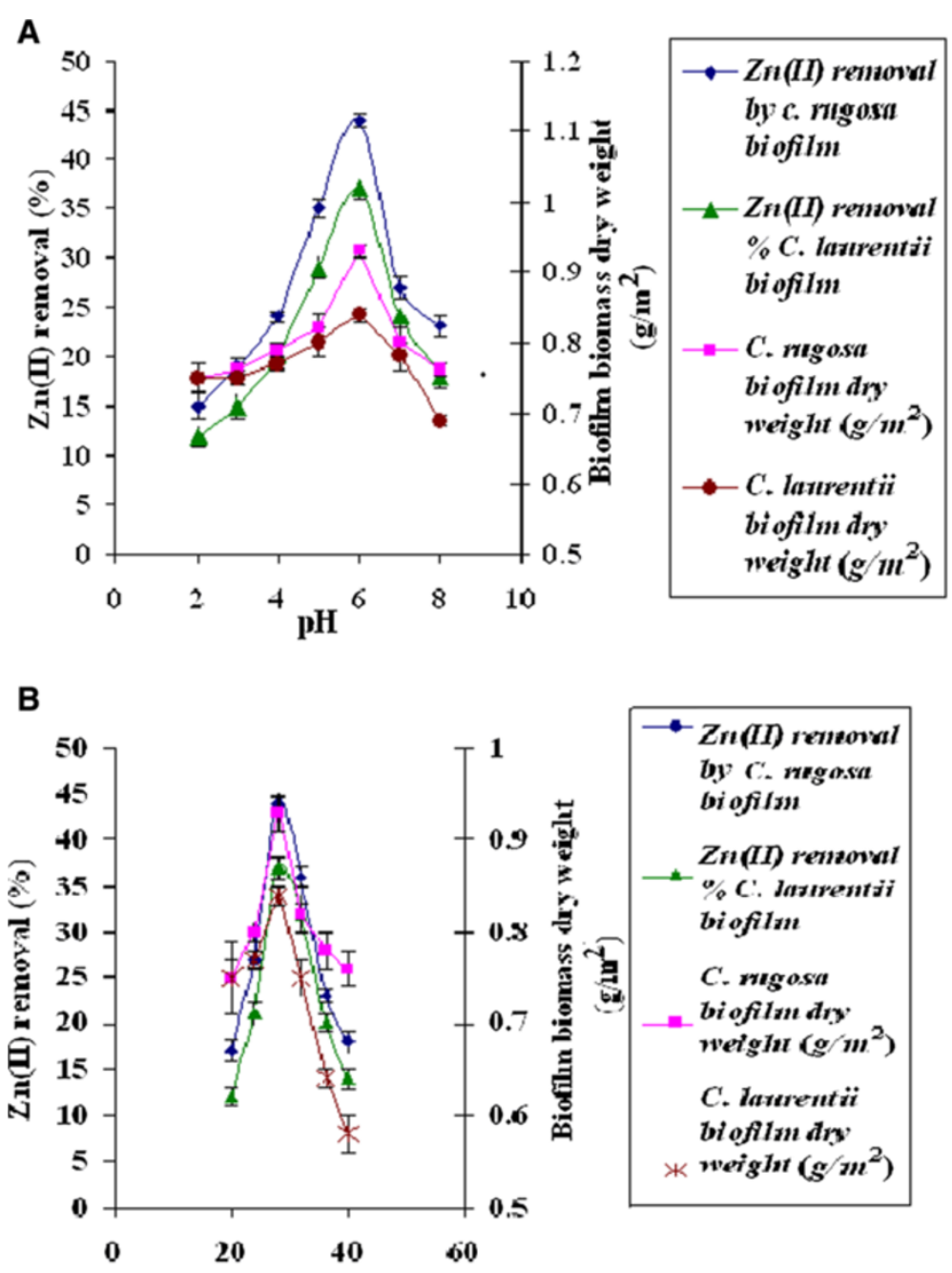

Temperature $\left({ }^{\circ} \mathrm{C}\right)$

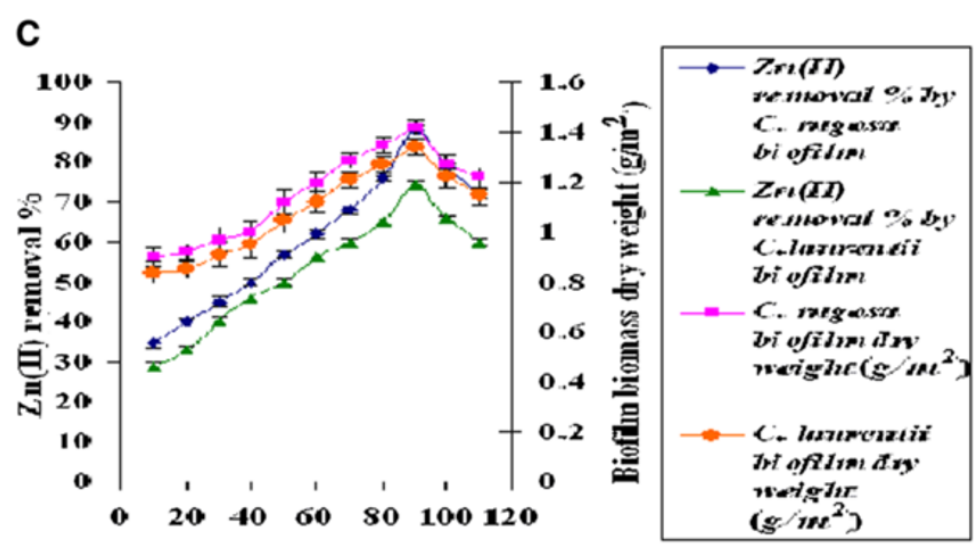

Initial Zn(II) concentantion (mg/L)

Figure 10 Effect of parameters on $\mathrm{Zn}(\mathrm{II})$ removal by yeast biofilm grown on sugarcane bagasse extract medium. (A) $\mathrm{pH}$ (temperature: $28^{\circ} \mathrm{C}$; contact time: $12 \mathrm{~h}$ ) (B) temperature (contact time: $12 \mathrm{~h} ; \mathrm{pH}: 6$ ) and (C) initial $\mathrm{Zn}(\mathrm{II})$ concentration (temperature: $28^{\circ} \mathrm{C}$; contact time: $12 \mathrm{~h}$; $\mathrm{pH}:$ 6.0). 

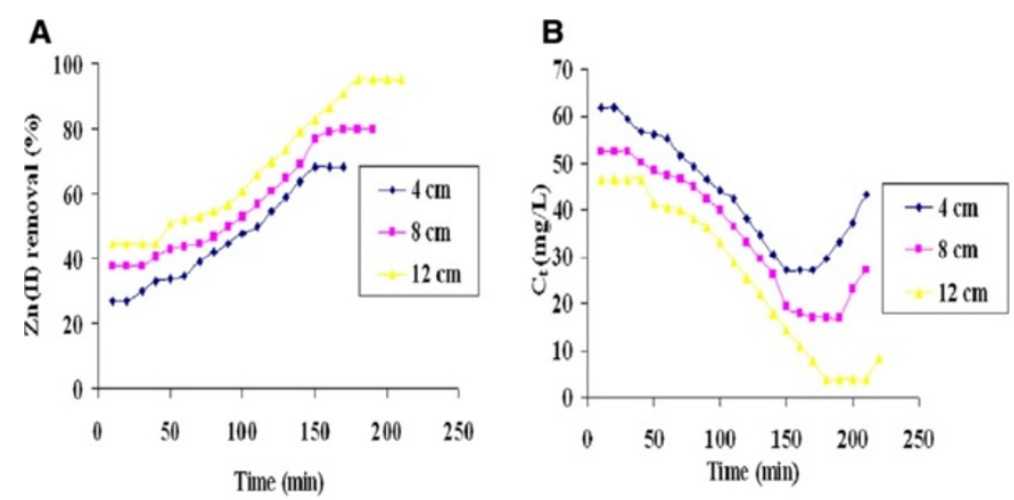

Figure 11 Removal of Zn(II) from industrial effluent by C.rugosa biofilm at different bed heights (A) Zn(II) removal percentage; (B) Breakthrough curve (Inlet $\mathrm{Zn}$ (II) concentration in the industrial effluent: $85 \mathrm{mg} / \mathrm{L}$; flow rate $1 \mathrm{~mL} / \mathrm{min} ; \mathrm{pH} ; 6.0$ ).

\section{Batch studies on $\mathrm{Zn}$ (II) removal using yeast biofilm formed on gravels}

Removal of $\mathrm{Zn}(\mathrm{II})$ ion using biofilm formed by C. rugosa and $C$. laurentii was tested in growth restricted (without sugarcane bagasse extract) and growth supportive (with sugarcane bagasse extract) media at $\mathrm{pH} 5$ and temperature $28^{\circ} \mathrm{C}$ for $12 \mathrm{~h}$. It was found that $\mathrm{Zn}$ (II) removal efficiency by yeast biofilm in growth supportive media was more compared to growth restricted media. In the growth supportive medium, Zn removal was $35 \%$ and $29 \%$ by $C$. rugosa and C. laurentii biofilms respectively, whereas in growth restricted medium $25 \%$ and $21 \% \mathrm{Zn}$ (II) ions was removed by $C$. rugosa and $C$. laurentii biofilms respectively. Therefore, further experiments were carried out with growth supportive media. In the growth supportive media, the doubling times of $C$. rugosa and $C$. laurentii were $90 \mathrm{~min}$ and $120 \mathrm{~min}$ respectively. Yeast is simple, economical, and rapid, with a doubling time in rich medium of approx $90 \mathrm{~min}$ to $140 \mathrm{mins}$. In addition to sugars, the aqueous extract of sugarcane bagasse also contained nitrogen compounds and other nutrients including sulphates, chlorides, phosphates, potassium, sodium, calcium, iron and copper [36] that enhanced the doubling time of the yeast species. The specific growth rate of $C$. rugosa and C. laurentii were found to be $0.135 \mathrm{~h}^{-1}$ and $0.129 \mathrm{~h}^{-1}$ respectively.

The effect of initial $\mathrm{pH}$ on $\mathrm{Zn}$ (II) removal and biofilm biomass was studied. The initial $\mathrm{pH}$ significantly affected the growth and $\mathrm{Zn}$ (II) removal properties of yeast biofilms. The $\mathrm{Zn}(\mathrm{II})$ removal efficiency and biofilm biomass increased when $\mathrm{pH}$ increased from 2-6 (Figure 10A). When $\mathrm{pH}$ is increased, the negatively charged ligands on the biofilm surface was exposed, resulting in the greater attraction for the cationic $\mathrm{Zn}(\mathrm{II})$ ion [37]. $\mathrm{pH} 6.0$ was chosen as optimum for the removal of $\mathrm{Zn}$ (II) ions by the yeast biofilm biomass. At $\mathrm{pH}$ 6.0, the main chemical groups viz. carboxyl, phosphate, sulfydryl, hydroxyl and nitrogen-containing groups of biofilm biomass surface might have participated in the removal of $\mathrm{Zn}$ (II) ion [38]. At optimum $\mathrm{pH}$ 6.0, C. rugosa biofilm showed maximum $\mathrm{Zn}(\mathrm{II})$ removal of $44 \%$ and biofim biomass dry wt. $0.93 \mathrm{~g} / \mathrm{m}^{2}$, whereas C. laurentii biofilm showed $37 \% \mathrm{Zn}(\mathrm{II})$ removal and biofilm biomass dry wt was $0.84 \mathrm{~g} / \mathrm{m}^{2}$ at $12 \mathrm{~h}$.
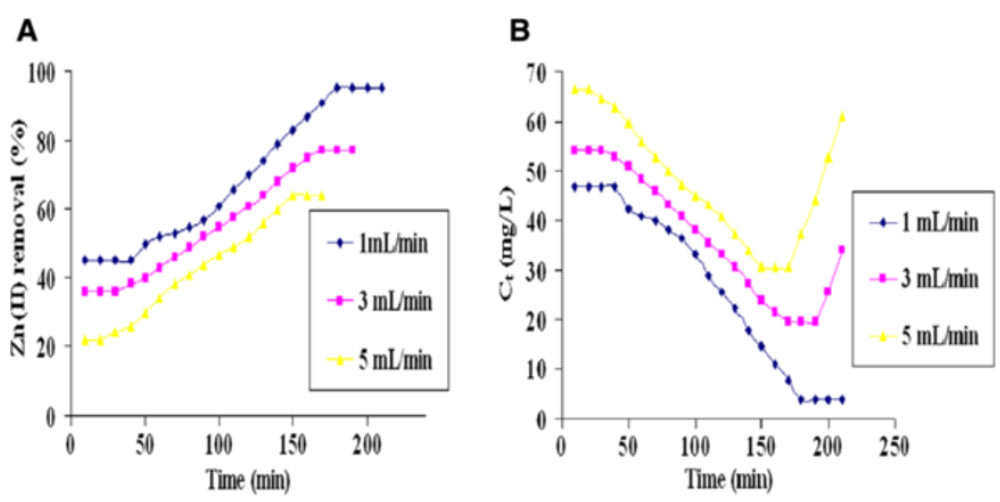

Figure 12 Removal of $\mathrm{Zn}$ (II) from industrial effluent by C. rugosa biofilm at different flow rates (A) $\mathrm{Zn}$ (II) removal percentage (B) Breakthrough curve (Inlet Zn(II) concentration in the industrial effluent: 85 mg/L; bed height: 12 cm; pH; 6.0). 
Table 1 Physico-chemical analysis of electroplating effluent

\begin{tabular}{lll}
\hline Parameters & Before treatment & After treatment \\
\hline pH & $7.63 \pm 0.17$ & $6.4 \pm 0.63$ \\
Conductivity $(\boldsymbol{\mu} \mathbf{\Omega})$ & $5.68 \pm 0.20$ & $2.1 \pm 0.02$ \\
TSS (mg/L) & $1310 \pm 3.7$ & $615 \pm 5.2$ \\
TDS (mg/L) & $1137 \pm 4.1$ & $550 \pm 4.5$ \\
COD (mg/L) & $61 \pm 1.2$ & $23 \pm 0.64$ \\
Zn(II) (mg/L) & $85 \pm 0.64$ & $4 \pm 0.4$ \\
$\mathrm{Cd}(\mathrm{II})(\mathbf{m g} / \mathbf{L})$ & $10 \pm 0.54$ & $1.8 \pm 0.09$ \\
$\mathbf{N i}(\mathrm{II})(\mathbf{m g} / \mathbf{L})$ & $21 \pm 0.76$ & $2.8 \pm 0.17$ \\
$\mathrm{Cu}(\mathrm{II})(\mathbf{m g} / \mathbf{L})$ & $20 \pm 0.43$ & $2.6 \pm 0.15$ \\
\hline
\end{tabular}

The temperature of sorption medium is important for energy dependent mechanisms in metal sorption by microorganisms [39]. The optimum temperature for $\mathrm{Zn}$ (II) removal by yeast biofilm biomass was found to be $28^{\circ} \mathrm{C}$ at $12 \mathrm{~h}$. (Figure 10B). At low temperature, the yeast biofilm biomass dry weight and $\mathrm{Zn}$ (II) removal was found to be less because the binding of $\mathrm{Zn}$ (II) onto yeast biofilm biomass took place only by passive uptake. Biofilm biomass dry weight and $\mathrm{Zn}$ (II) removal was found to be minimum at higher temperature. Higher temperatures inhibited the yeast growth due to reduced enzymatic activity [40].

Experiments were performed to study the effects of initial metal concentration on $\mathrm{Zn}$ (II) removal by yeast biofilm. Zinc removal efficiency was increased with increase in initial $\mathrm{Zn}(\mathrm{II})$ concentration ranging from $10 \mathrm{mg} / \mathrm{L}$ to 90 $\mathrm{mg} / \mathrm{L}$ (Figure 10C). Maximum removal of $\mathrm{Zn}(\mathrm{II})$ ion by yeast biofilm occurred at $90 \mathrm{mg} / \mathrm{L}$. The increase in initial $\mathrm{Zn}$ concentration increased the driving force to overcome mass transfer resistance of metal ion between aqueous and solid phases [41]. In this study, $\mathrm{Zn}$ (II) removal efficiency of C. rugosa and C. laurentii biofilm was found to be $88 \%$ and $74.2 \%$ of $90 \mathrm{mg} / \mathrm{L}$ respectively. The maximum biofilm biomass (dry wt) produced by C. rugosa was 1.42 $\mathrm{g} / \mathrm{m}^{2}$ and C. laurentii was $1.34 \mathrm{~g} / \mathrm{m}^{2}$ at $12 \mathrm{~h}$.

\section{Treatment of effluent in column mode using yeast biofilm formed on gravels}

The C. rugosa biofilm formed on gravels was employed for the treatment of effluent in a continuous column mode. Figure $11 \mathrm{~A}$ and Figure $11 \mathrm{~B}$ showed the removal percentage and breakthrough curves of $\mathrm{Zn}$ (II) ion removal respectively at different bed heights. The removal percentage of $\mathrm{Zn}$ (II) ion increased from $68.12 \%$ to $95.29 \%$ with the increase in bed height from $4 \mathrm{~cm}$ to $12 \mathrm{~cm}$ at the flow rate of $1 \mathrm{~mL} / \mathrm{min}$ (Figure 11A). The breakthrough time $\left(t_{b}\right)$ and the exhaustion time $\left(t_{e}\right)$ increased with the increase in bed height (Figure 11B). High percentage of $\mathrm{Zn}$ (II) removal was noted at maximum bed height $12 \mathrm{~cm}$.
The effect of flow rate on $\mathrm{Zn}$ (II) removal was also evaluated using three different flow rates (1, 3 and 5 $\mathrm{mL} / \mathrm{min}$ ) at optimum bed height of $12 \mathrm{~cm}$. Figure 12A depicted that as the flow rate decreased from 5 to 1 $\mathrm{mL} / \mathrm{min}$, the $\mathrm{Zn}(\mathrm{II})$ removal percentage increased from 64 to $95.29 \%$. Figure $12 \mathrm{~B}$ showed that an increase in flow rate resulted decrease in breakthrough and exhaustion times due to insufficient residence time of the metal ions in the column [42]. Therefore, the maximum $\mathrm{Zn}$ (II) removal of $95.29 \%$ was obtained in the column mode at the highest bed height $(12 \mathrm{~cm})$ and the lowest flow rate $(1 \mathrm{~mL} / \mathrm{min})$. The total residence time was 180 minutes and the biofilm biomass dry weight was found to be $2.98 \mathrm{~g} / \mathrm{m}^{2}$ for the $\mathrm{Zn}$ (II) removal upto $95.29 \%$, leaving $4 \mathrm{mg} / \mathrm{L}$ residual $\mathrm{Zn}(\mathrm{II})$ ion in the treated effluent. The residual concentration of $\mathrm{Zn}$ (II) in the treated effluent was less than the US EPA standard $\left(5.0 \mathrm{mg} \mathrm{L}^{-1}\right)$. The physicochemical characteristics of the effluent before and after treatment in the column are shown in the Table 1. There was significant difference in the physicochemical properties of industrial effluent after biofilm treatment. The residual concentrations of other metals viz. $\mathrm{Ni}(\mathrm{II}), \mathrm{Cd}(\mathrm{II})$ and $\mathrm{Cu}(\mathrm{II})$ were found to be $2.8 \mathrm{mg} / \mathrm{L}$, $1.8 \mathrm{mg} / \mathrm{L}$ and $2.6 \mathrm{mg} / \mathrm{L}$ respectively. These residual concentrations were less than the permissible limits of each metal.

\section{Conclusions}

The present study showed the capability of the yeast species to form biofilm onto natural substrate like gravels. The EPS characterization study showed that extrapolymeric substances produced by the yeast species are made up of glucose, mannose and glucuronic acid subunits which would protect the cells from environmental chemical toxicity. This study gives an insight about the ability of artificially formed yeast biofilms on gravels to remove $\mathrm{Zn}$ (II) ions from aqueous solution as an inexpensive and alternative method to traditional techniques for removal of $\mathrm{Zn}(\mathrm{II})$ from waste waters. The potentiality of C. rugosa biofilm for removal of $\mathrm{Zn}$ (II) ions from real effluent was also studied in column mode.

\section{Competing interests}

The authors declare that they have no competing interest.

\section{Authors' contribution}

GB, LV and ND participated in the design of the study and draft the manuscript. GB carried out the experimental studies. PC helped for the instrumental analyses. ND corrected the manuscript. All the authors finally approved the manuscript.

\section{Acknowledgements}

Authors of this article would like to thank VIT University for providing Lab facility and financial support for the smooth conduct of the work. We also extend our gratitude towards Pondicherry University for the assistance in SEM analysis. The efforts provided by Sastra University for CLSM analysis is greatly acknowledged. 


\section{Author details}

'Environmental Biotechnology Division, School of Bio- Sciences and Technology, VIT University, Vellore, Tamil Nadu, India. ${ }^{2}$ School of Chemical and Biotechnology, SASTRA University, Thanjavur, Tamil Nadu, India.

Received: 27 February 2013 Accepted: 6 October 2013

Published: 7 January 2014

\section{References}

1. The Council of the European Communities: Directive $76 / 464 / \mathrm{EEC}$ on pollution caused by certain dangerous substances discharged into the aquatic environment of the community. Off J Eur Commun 1976. No. L 129/23.

2. Ramos RL, Jacome LAB, Barron JM, Rubio LF, Coronado RMG: Adsorption of zinc(II) from an aqueous solution onto activated carbon. J Hazard Mater 2002, B90:27-38.

3. Mohan D, Singh KP: Single and multi-component adsorption of cadmium and zinc using activated carbon derived from bagasse - an agricultural waste. Water Res 2002, 36:2304-2318.

4. Norton L, Baskaran K, McKenzie ST: Biosorption of zinc from aqueous solutions using biosolids. Adv Environ 2004, 8:629-635.

5. Li H, Lin Y, Guan W, Chang J, Xu L, Guo J, Wei G: Biosorption of Zn(II) by live and dead cells of Streptomyces ciscaucasius Starin CCNWHX 72-14. J Hazard Mater 2010, 179:151-159.

6. Kumar R, Singh R, Kumar N, Bishnoi K, Bishnoi NR: Response surface methodology approach for removal of $\mathrm{Cr}(\mathrm{VI}), \mathrm{Ni}(\mathrm{II})$ and $\mathrm{Zn}(\mathrm{II})$ ions by immobilized bacterial biomass sp. Bacillus brevis. Chem Eng J 2009, 146:401-407.

7. Vasquez TGP, Botero AEC, de Mesquita LMS, Torem ML: Biosorptive removal of $\mathrm{Cd}$ and $\mathrm{Zn}$ from liquid streams with a Rhodococcus opacus strain. Minerals Eng 2007, 20:939-944.

8. Velmurugan P, Shim J, You Y, Choi S, Kannan SK, Lee KJ: Removal of zinc by living, dead, and dried biomass of Fusarium spp. Isolated from the abandoned -metal mine in South Korea and its perspective of producing nanocrystals. J Hazard Mater 2010, 182:317-324

9. Fan T, Liu Y, Feng B, Zeng G, Yang C, Zhou M: Biosorption of Cadmium (II), Zinc (II) and lead (II) by Penicillium simplicissimum: Isotherms, Kinetics and thermodynamics. J Hazard Mater 2008, 160:655-661.

10. Chen C, Wang J: Influence of metal ionic characteristics on their biosorption capacity by Saccharomyces cerevisia. Appl Microbiol Biotechnol 2007, 74:911-917.

11. Chen C, Wang J: Investigating the interaction mechanism between zinc and Saccharomyces cerevisiae using combined SEM-EDX and XAFS. Appl Microbiol Biotechnol 2008, 79:293-299.

12. Das D, Basak G, Lakshmi V, Das N: Kinetics and equilibrium studies on removal of Zinc(II) by untreated and anionic surfactant treated dead biomass of yeast: batch and column mode. Biochem Eng J 2012, 64:30-47.

13. Scott JA, Karanjkar AM, Rowe DL: Biofilm covered granular activated carbon for decontamination of streams containing heavy metals and organic chemicals. Miner Eng 1995, 8:221-230.

14. Scott JA, Karanjkar AM: Immobilized biofilms on granular activated carbon for removal and accumulation of heavy metals from contaminated streams. Water Sci Technol 1998, 38:197-204

15. Diels L, Roy SV, Somers K, Willems I, Doyen W, Mergeay M, Springael D: The use of bacteria immobilized in tubular membrane reactors for heavy metal recovery and degradation of chlorinated aromatics. J Memb Sci 1995, 100:249-258.

16. Chang WC, Hsu GS, Chiang SM, Su MC: Heavy metal removal from aqueous solution by wasted biomass from a combined AS-biofilm process. Bioresour Technol 2006, 97:1503-1508.

17. Saravanan P, Prabagaran SR, Nancharaiah YV, Krishnaveni M, Venugopalan VP, Jayachandran S: Isolation and characterization of Pseudoalteromonas ruthenica (SBT033), an EPS producing biofilm bacterium from the sea water intake point of a tropical power station. World I Microbiol Biotechnol 2008, 24(4):509-515.

18. Omoike A, Chorover J: Spectroscopic study of extracellular polymeric substances from Bacillus subtilis: aqueous chemistry and adsorption effects. Biomacromolecules 2004, 5:1219-1230.

19. Eboigbodin KE, Biggs CA: Characterization of the extracellular polymeric substances produced by Escherichia coli using infrared spectroscopic, proteomic, and aggregation studies. Biomacromolecules 2008, 9(2):686-695.
20. Comte S, Guibaud G, Baudu M: Biosorption of properties if exrapolymeric substances (EPS) resulting from activated sludge according to their type: soluble or bound. Process Biochem 2006, 41:815-823.

21. Lal P, Sharma D, Pruthi P, Pruthi V: Exopolysaccharide analysis of biofilmforming Candida albicans. J Appl Microbiol 2009, 109:128-136.

22. APHA: Standard Methods of Water and Effluent Examination. USA: American Public Health Association; 1995

23. Hawser SP, Douglas L: Biofilm formation by Candida species on the surface of the catheter materials in vitro. Infect Immun 1994, 64:287-295.

24. Sundar K, Sadiq M, Mukherjee A, Chandrasekaran N: Bioremoval of trivalent chromium using Bacillus biofilms through continuous flow reactor. J Hazard Mater 2011, 196:44-51.

25. McCourtie J, Douglas ப: Extracellular polymer of Candida albicans: isolation, analysis and role in adhesion. J Gen Microbiol 1985, 131:495-503.

26. Simova ED, Frengova Gl, Beshkova DM: EPS produced by mixed culture of yeast Rhodotorula rubra GED10 and yogurt bacteria (Streptococcus thermophilus 13a + Lactobacillus bulgaricus 2-11). J Appl Microbiol 2004, 97:512-519.

27. Chandran P, Das N: Degradation of diesel oil by immobilized Candida tropicalis and biofilm formed on gravels. Biodegradation 2011, 22:1181-1189.

28. Chiru H, Izuka M, Yamamoto T: A glucomannan as an extracellular product of Candida utilis.I. Production and characterisation of a glucomannan. Agri Biol Chem 1982, 46:1723-1733.

29. Chiru H, Izuka M, Yamamoto T: A glucomannan as an extracellular product of Candida utilis.ll. Structure of a glucomannan characterization of oligosaccharides obtained by partial hydrolysis. Agri Bio IChem 1982, 46:1733-1742

30. Pavlova K, Panchev I, Kranchanova M, Gocheva M: Production of an exopolysaccharide by Antartic yeast. Folia Microbiol 2009, 54:343-348.

31. Peterson GR, Nelson GA, Cathey CA, Fuller GG: Rheologically interesting polysaccharides from yeasts. Appl Biochem Biotechnol 1989, 20:845-867.

32. Bremer PJ, Geesey GG: An evaluation of biofilms development utilizing non-destructive attenuated total reflectance Fourier transform infrared spectroscopy. Biofouling 1991, 3:89-100

33. Bramhachari PV, Dubey SK: Isolation and characterization of exopolysaccharide produced by Vibrio harveyi strain VB23. Lett Appl Microbiol 2006, 43:571-577.

34. Peng $Y$, Zhang $F, X U$ Y: Structure and antimour activity of EPS from mycelium. Carbohydr Polym 2003, 54:297-303.

35. Ma Y, Shen B, Sun R, Zhou W, Zhang Y: Lead(II) biosorption of an antartic sea ice bacterial exopolysaccharide. Desalin Water Treat 2012, 42:200-209.

36. Basak G, Charumathi D, Das N: Combined effects of sugarcane bagasse extract and Zinc(II) ions on the growth and bioaccumulation properties of yeast isolates. IJEST 2011, 3:6321-6334.

37. Yu J, Tong M, Su X, Li B: Cystine-modified biomass for $\mathrm{Cd}(\mathrm{II})$ and Pb(II) biosorption. J Hazard Mater 2006, 132:126-139.

38. Martell A-E, Smith R-M: NIST Standard Reference Database 46 Version 8.0, NIST Critically Selected Stability Constants of Metal Complexes Database. US Department of Commerce, National Institute of Standards and Technology; 2004.

39. Bayramoglu G, Bektas S, Arica MY: Biosorption of heavy metal ions on immobilzed white rot fungus Trametas versicolor. $J$ Hazard Mater 2003, 101:285-300.

40. Uslu G, Dursun AY, Ekiz HI, Aksu Z: The effect of Cd (II), Pb (II) and Cu (II) ions on the growth and bioaccumulation properties of Rhizopus arrhizus. Process Biochem 2003, 39:105-110.

41. Yin $\mathrm{H}, \mathrm{He}$ B, Peng H, Ye J, Yang F, Zang N: Removal of $\mathrm{Cr}(\mathrm{VI})$ and Ni(II) from aqueous solution by fused yeast: study of cations release and biosorption mechanism. J Hazard Mater 2008, 158:568-576.

42. Muhamad H, Doan $\mathrm{H}$, Lohi A: Batch and continuous fixed-bed column biosorption of $\mathrm{Cd}^{2+}$ and $\mathrm{Cu}^{2+}$. Chem Eng J 2010, 158:369-377.

doi:10.1186/2052-336X-12-8

Cite this article as: Basak et al:: Removal of $\mathrm{Zn}$ (II) from electroplating effluent using yeast biofilm formed on gravels: batch and column studies. Journal of Environmental Health Science \& Engineering 2014 12:8. 